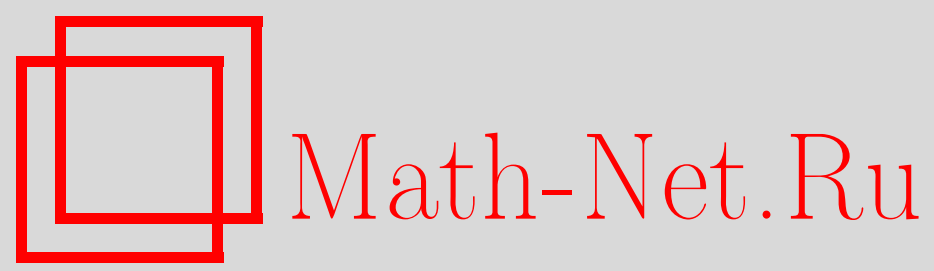

А. Ю. Родичев, Электронная цифровая подпись и законодательство РФ, Вестн. Сам. гос. техн. ун-та. Сер. Физ.-мат. науки, 2003, выпуск 19, 190-193

DOI: https://doi.org/10.14498/vsgtu168

Использование Общероссийского математического портала Math-Net.Ru подразумевает, что вы прочитали и согласны с пользовательским соглашением

http://www.mathnet.ru/rus/agreement

Параметры загрузки:

IP : 54.197 .130 .99

26 апреля 2023 г., $17: 49: 53$ 


\title{
Правовая информатика
}

\author{
УДК 342.9
}

А.Ю. Родичев

\section{ЭЛЕКТРОННАЯ ЦИФРОВАЯ ПОДПИСЬ И ЗАКОНОДАТЕЛЬСТВО РФ}

Рассмотрены вопросы использования электронной циифровой подписи (ЭЦП) в правоприменительной практике, доказательственной силь электронного документа, дан обзор законодательньх актов, регулирующих информаџионно-коммуникационные технологии (ИКТ) $и$, в частности, ЭЦП. Обозначены приоритетные направления взаимодействия ИКТ и законодательства, подчеркнута актуальность полного и непротиворечивого регулирования ИКТ современным законодательством.

В современном мире новые информационно-коммуникационные технологии (ИКТ) развиваются очень стремительно, тем самым появляются новые области, требующие законодательного регулирования. Одним из актуальных в настоящее время направлений являются системы электронного документооборота, позволяющие не только технически защитить информацию, быстро ее передать по каналам связи, в том числе по сети Интернет, но и придать юридическую значимость электронному документу посредством подписания документа ЭЦП, гарантирующей целостность и подлинность.

Основной принцип ЭЦП строится на базе асимметричного алгоритма шифрования, суть которого заключается в том, что зашифровывается документ одним ключом (закрытый ключ), а расшифровывается другим (открытый ключ). ЭЦП представляет собой определенный набор цифр, приписанных к документу, полученная в результате обсчета документа специальным математическим алгоритмом (хеш-функция) [1] и зашифрованная секретным ключом отправителя. ЭЦП должна содержать указание на хеш-функцию (метод вычисления хеш-функции). Получатель документа, используя открытый ключ, расшифровывает хеш-значение полученного документа и сравнивает его с фактическим хеш-значением, применив к документу соответствующую хеш-функцию. Если значения совпадают, следовательно, документ был подписан истинным владельцем и во время пути не претерпел изменения. Необходимо отметить, что между средствами шифрования и средствами ЭЦП есть как сходства, так и различия. Сходство заключается в использовании математического алгоритма шифрования с применением закрытого ключа. Различие кроется в предназначении ЭЦП и средств шифрования. Так, ЭЦП удостоверяет подлинность сообщения, а средства шифрования - конфиденциальность.

Существует несколько алгоритмов шифрования. Нужно отметить, что некоторые из них, в свое врем считавшиеся надежными, сейчас таковыми не являются. Например, известный алгоритм DES (Data Encryption Standard), разработанный в 1970 г., был удачно взломан за короткое время с использованием системы распределенных вычислений [2]. В данном случае техническая сторона шифрования тесно связана с юридической и если алгоритм не надежен, то стоит подумать о его правоприменительной практике.

Насколько полно раскрывает понятие «электронный документооборот» настоящее законодательство? В соответствии со ст. 2 ФЗ РФ от 20 февраля 1995 г. "Об информации, информатизации и защите информации” документированная информация (документ) - зафиксированная на материальном носителе информация с реквизитами, позволяющими ее идентифицировать. Согласно ст. 3 ФЗ РФ от 10 января 2002 г. “Об электронной цифровой подписи” электронный документ - документ, информация в котором представлена в электронно-цифровой форме. В последнее время обсуждается необходимость принятия единого специализированного законодательства по электронному документообороту, регламентирующего порядок применения систем электронного документооборота. Но отсутствие такового породило принятие подведомственных актов [3], которые не обладают общей терминологической базой, узко специализированны, что говорит об отсутствии системного подхода.

В арбитражном процессуальном кодексе РФ (АПК) уже определен статус ИКТ, предоставляющий возможность использования электронного документооборота в арбитражном процессе с помощью электронной почты. 
В соответствии с АПК электронную почту можно применять в следующих случаях: заявление об обеспечении иска (ст. 92), судебные извещения (ст. 121), исковое заявление (ст. 125), отзыв на исковое заявление (ст. 131), требования к заявлению об отмене решения третейского суда (ст. 231), требования к заявлению о выдаче исполнительного листа на принудительное исполнение решения третейского суда (ст. 237), заявление о признании и приведении в исполнение решения иностранного суда и иностранного арбитражного решения (ст. 242), апелляционная жалоба (ст. 260), кассационная жалоба (ст. 277), заявление или представление о пересмотре судебного акта в порядке надзора (ст. 294), заявление о пересмотре судебного акта по вновь открывшимся обстоятельствам (ст. 313).

Использование электронной почты поднимает ряд технических вопросов, связанных с надежностью информационно-коммуникационных технологий. Так, согласно п.2 ст. 123 АПК РФ: лица, участвующие в деле, и иные участники арбитражного процесса также считаются извещенными надлежащим образом арбитражным судом, если: 1) адресат отказался от получения копии судебного акта и этот отказ зафиксирован; 2) несмотря на почтовое извещение, адресат не явился за получением копии судебного акта, направленной арбитражным судом в установленном порядке, о чем орган связи проинформировал арбитражный суд; 3) копия судебного акта, направленная арбитражным судом по последнему известному суду месту нахождения организации, месту жительства гражданина, не вручена в связи с отсутствием адресата по указанному адресу, о чем орган связи проинформировал арбитражный суд.

Из этого можно сделать вывод, что если судебное извещение, отправленное арбитражным судом по электронной почте, получено провайдером Интернет услуг, но при этом адресат по каким-либо причинам не прочитал данное извещение, то он будет считаться извещенным надлежащим образом. Причем, возможно, что адресат именно по техническим причинам (например не работает оборудование провайдера, повреждены каналы передачи данных) не смог связаться с сервером провайдера. Кроме этого, технически возможна подделка электронного письма, например посредством подмены имени и адреса реального отправителя, текста письма. Таким образом, необходима доработка процедуры извещения и подтверждения доставки с использованием электронной почты, а также предусмотреть возможность использования ЭЦП, гарантирующей целостность и подлинность документов.

В 1995 г. ЭЦП технически была определена следующими ГОСТами: ГОСТ Р. 34.10-94 «Информационные технологии». Криптографическая защита информации. Процедура выработки и проверки электронной цифровой подписи на базе криптографического алгоритма и ГОСТ P. 34.11-94 «Информационные технологии. Криптографическая защита информации. Функция хеширования". Разработаны оба документа главным управлением безопасности связи Федерального агентства правительственной связи и информации и Всероссийским научноисследовательским институтом стандартизации. Первый стандарт определяет процедуры выработки и проверки электронной цифровой подписи на базе асимметричного криптографического алгоритма с применением функции хэширования. Второй стандарт определяет процедуру вычисления хэш-функции для любой последовательности двоичных символов. Функция хэширования заключается в сопоставлении произвольного набора данных в виде последовательности двоичных символов и его образа фиксированной небольшой длины, что позволяет использовать эту функцию в процедурах электронной цифровой подписи для сокращения времени подписывания и проверки подписи. Эффект сокращения времени достигается за счет вычисления подписи только под образом подписываемого набора данных.

Гражданский кодекс РФ (ГК РФ) юридически закрепил возможность использования ЭЦП. Так, согласно ГК РФ, договор может быть заключен в любой форме, предусмотренной для совершения сделок. Причем договор в письменной форме может быть заключен путем составления одного документа, подписанного сторонами, а также путем обмена документами посредством почтовой, телеграфной, электронной или иной связи, позволяющей достоверно установить, что документ исходит от стороны по договору. Использование при совершении сделок электронной цифровой подписи либо иного аналога собственноручной подписи допускается в случаях и в порядке, предусмотренных законом, иными правовыми актами или соглашением сторон (ст. 160, 434 ГК РФ).

20 февраля 1995 г. был принят закон “Об информации, информатизации и защите информации". Согласно ст. 5 закона, юридическая сила документа, хранимого, обрабатываемого и передаваемого с помощью автоматизированных информационных и телекоммуникационных систем, может подтверждаться электронной цифровой подписью. Юридическая сила электронной цифровой подписи признается при наличии в автоматизированной информационной сис- 
теме программно-технических средств, обеспечивающих идентификацию подписи, и соблюдении установленного режима их использования.

10 января 2002 г был принят Федеральный закон “Об электронной цифровой подписи” (далее закон “Об ЭЦП”), регулирующий правовые отношения и обеспечивающий правовые условия электронной цифровой подписи в электронных документах, при соблюдении которых электронная цифровая подпись в электронном документе признается равнозначной собственноручной подписи в документе на бумажном носителе. Необходимо отметить, что деятельность корпоративных систем по использованию электронной цифровой подписи полностью урегулирована ГК РФ и в данной области не требуется применения закона "Об ЭЦП“. Но если говорить об открытой системе обмена электронными документами, то здесь правовым регулированием отношений в области использования ЭЦП и призван заниматься данный закон, который предполагает создание удостоверяющих центров для регистрации участников и выдачи сертификатов ключей подписи.

В соответствии со ст. 160 ГК РФ помимо ЭЦП возможно использование иного аналога собственноручной подписи при совершении сделок. К сожалению, указанный закон "Об ЭЦП”, а также закон "Об информации, информатизации и защите информации" из всех систем цифровых подписей предлагает только электронную цифровую подпись, тем самым сужая возможное использование аналогов собственноручной подписи.

Как же обстоит дело с доказательственной силой электронного документа? Впервые вопрос о доказательственной силе электронного документа получил отражение в Инструктивных указаниях Госарбитража СССР № И-1-4 от 1979 г. «Об использовании в качестве доказательств по арбитражным делам документов, подготовленных с помощью электронно-вычислительной техники». В Указаниях сказано, что стороны по арбитражным делам в обоснование своих требований и возражений вправе представлять арбитражам документы, подготовленные с помощью электронно-вычислительной техники. Эти документы, поскольку они содержат данные об обстоятельствах, имеющих значение для дела, должны приниматься органами арбитража на общих основаниях в качестве письменных доказательств. Данные, предоставленные на техническом носителе, должны быть преобразованы в форму, пригодную для восприятия и хранения.

Следующим важным документом в обеспечении доказательственной силы ЭД стоит рассматривать Письмо Высшего Арбитражного Суда РФ от 19 августа 1994 г. № С1-7/ОП-587 «Об отдельных рекомендациях, принятых на совещаниях по судебно-арбитражной практике». В Письме говорится, что если стороны изготовили и подписали договор с помощью электронновычислительной техники, в которой использована система цифровой (электронной) подписи, они могут представлять в арбитражный суд доказательства по спору, вытекающему из этого договора, также заверенные цифровой (электронной) подписью. В случае возникновения между сторонами спора о наличии договора и других документов, подписанных цифровой (электронной) подписью, арбитражный суд запрашивает у сторон выписку из договора, в котором указана процедура порядка согласования разногласий, на какой стороне лежит бремя доказывания тех или иных фактов и достоверности подписи.

Кроме этого, Высший арбитражный суд РФ принял письмо № C1-7/О3-316 «О Федеральном законе «Об информации, информатизации и защите информации»», в котором обращалось внимание на то, что при соблюдении условий, предусмотренных ст. 5 Закона, в том числе при подтверждении юридической силы документа ЭЦП, этот документ может признаваться в качестве доказательства по делу, рассматриваемому арбитражным судом.

Следует упомянуть ГОСТ 6.10.4-84 от 1984 г. «Придание юридической силы документам на машинном носителе и машинограмме, создаваемым средствами вычислительной техники», определяющий состав и содержание реквизитов, придающих юридическую силу документам на машинном носителе. Документ предполагает наличие специального договора о порядке обмена документами на машинном носителе.

Необходимо отметить, что в России уже имеется судебная практика по рассмотрению судом финансового спора с привлечением электронного документа в качестве доказательства. Так, юридическая компания "Юкон” предъявила иск к своему заказчику Межбанковскому финансовому дому по поводу несоблюдения условий договора об оплате услуг, который к тому же был подписан ЭЦП и в дальнейшем послужил доказательством в суде.

Развитие ИКТ опережает принятие соответствующих законодательных норм и процедур для полноценного регулирования данной области, что негативно сказывается на развитии электронной коммерции, применении системы электронных расчетов между населением и государством. В настоящее время нет единой политики в сфере правового регулирования ИКТ и соот- 
ветственно государственного органа полностью за это ответственного. Полагаю, необходима специальная программа развития законодательства в области ИКТ, полно и непротиворечиво регламентирующего указанную область.

\section{БИБЛИОГРАФИЧЕСКИЙ СПИСОК}

1. ГОСТ «Информационная технология. Криптографическая защита информации. Функция хэширования» (Р 34.11 94 введен с 1 января 1995 г.). М.: Изд-во стандартов, 1995.

2. Милз Э. Программы шифрования на свободе // Computer-World Россия. 1999. 9 февраля.

3. “Об утверждении требований к форматам и структуре электронных сообщений при обмене информацией между органами федерального казначейства и налоговыми органами”; Приказ МФ РФ и МНС РФ от 25 июня “Об организации и функционировании системы представления налоговых деклараций и бухгалтерской отчетности в электронном виде по телекоммуникационным каналам связи"; 2001 Приказ МНС РФ от 10.12.2002Постановление Правления ПФ РФ от 26.01.2001 "О введении в системе пенсионного фонда Российской Федерации криптографической защиты информации и электронной цифровой подписи".

Поступила 5.03.2003 г. 